\title{
Communication of soil water repellency causes, problems, and solutions of intensively managed amenity turf from 2000 to 2020
}

\author{
Michael Fidanza ${ }^{1 *}$, Stanley Kostka $^{1}$, Cale Bigelow ${ }^{2}$ \\ ${ }^{1}$ Division of Science, Berks Campus, Pennsylvania State University, 111 Luerssen Building, Reading, PA 19610 USA. \\ 2 Department of Horticulture and Landscape Architecture, Purdue University, West Lafayette, IN 47907 USA. \\ * Corresponding author. E-mail: maf100@psu.edu
}

\begin{abstract}
Research and investigations of soil water repellency in turfgrass science is a relatively recent endeavor, with most notable progress beginning in the late 1990s and early 2000s and continuing into the present. The objectives of this review were to determine the extent of publications from 2000 to the present on the topic of soil water repellency in turfgrass science, and to assemble a list of soil surfactant product formulations currently available for the amenity turf industry in the USA and United Kingdom/Republic of Ireland in 2019. From 1 January 2000 through 1 June 2020, cumulative number of referred or peer-reviewed research journal articles was 64, the number of abstracts, reports, and proceedings was 87 , and the number of professional and trade journal articles was 86 . Published works in all categories represented a linear increase over time, and is indicative of increased research activity into this critical area of study. Soil surfactant products and formulations in the USA totaled 192, with 65 in UK/Ireland. The nonionic soil surfactant chemical category is the largest, representing $74 \%$ of products in the USA, and $66 \%$ of products in UK/Ireland. With formulation category, block copolymers and formulations that contain block copolymers or structurally modified block copolymers as a formulation component comprise the largest group with $58 \%$ of products in the USA, and $49 \%$ of products in UK/Ireland. Also by formulation category, $25 \%$ of USA products and $23 \%$ of UK/Ireland products are comprised of anionic and anionic blends and other formulations. Of note, $17 \%$ of products in the USA and $28 \%$ of products in UK/Ireland do not disclose their formulation.

Dr. Louis Dekker's pioneering insight and advances in soil water repellency has provided turfgrass scientists with a firm foundation and guidance with which to pursue research into the causes, problems, and amelioration of soil water repellency in turfgrass ecosystems. The global amenity turf industry remains the segment where Dr. Dekker's research has had the most influence and impact to both scientists and turf practitioners.
\end{abstract}

Keywords: Soil hydrophobicity; Soil surfactants; Turfgrass science; Golf courses; Sports pitches; Localized dry patch; Rootzone.

\section{INTRODUCTION}

Within the discipline of soil science, the concept and associated causes, characteristics, and consequences of soil water repellency has been extensively studied in agriculture and natural ecosystems (DeBano, 2000; DeBano and Dekker, 2000; Dekker and Ritsema, 1994; Doerr et al., 2000; Hallett, 2008; Wallis and Horne,1992) and research continues to expand our understanding of this important topic (Dekker et al., 2005), which also includes investigations on methods for remediation and management (Müller and Deurer, 2011). The study of soil water repellency in turfgrass science is a relatively recent endeavor.

Water repellent soils in turfgrass culture was first mentioned in reports by Letey et. al $(1963,1969)$ and DeBano and Letey (1969). The first extensive observations of soil water repellency associated with managed turf, as related to localized dry spots or dry patches on golf course putting greens, was published by Snyder (1969) and subsequently by Miller and Wilkinson (1977) and Wilkinson and Miller (1978). After more than a decade gap in this research area, Wallis et al. (1990) investigated soil water repellency in sand in New Zealand, which was extrapolated to include sands used in turf culture, and Tucker et al. (1990) documented soil water repellency issues on sand rootzones of golf course turf in Georgia (USA). Shortly after, Cisar and Williams (1994) reported on the phenomenon occur- ring in south Florida (USA). Cisar et al. (1997) and Kostka et. al. (1997), however, published some of the first refereed journal articles specifically addressing soil water repellency management in turf.

Dr. Louis Dekker was instrumental in advancing our understanding of soil water repellency in turfgrass rootzones (Dekker et al., 2001b; Kostka and Fidanza, 2019a; Kostka et al., 2002). An international workshop on soil water repellency, organized by Ritsema and Dekker (2003), brought together researchers from multiple disciplines but all with an interest in this phenomenon. That three-day meeting provided a unique opportunity for collaboration and interdisciplinary cooperation among scientists to conduct global research on soil water repellency. Where there had once been considerable insularity within soil science sub-disciplines, there were now crossdisciplinary collaboration. By 2000 , more research was published on the phenomenon and issues of soil water repellency in turf by York and Canaway (2000) and Dekker et al. (2001a), followed by others (Kostka et al., 2005; McMillan et al., 2013; Moody et al., 2009; Schlossberg et al., 2005), as well as methods to alleviate soil water repellency problems in managed turfgrass swards (Cisar et al., 2000; Dekker et al., 2003; Kostka, 2000; Kostka et al., 2007a; Park et al., 2004).

Since the early $2000 \mathrm{~s}$, and beginning with that international workshop on soil water repellency, there has been a continuous and consistent record of research published on the topic of soil 
water repellency within the discipline of turfgrass science, soil physics, ecology, and biohydrology. Also since the early 2000s, there has been a steady effort with publishing research-based methods to ameliorate soil water repellency in turf with the use of soil surfactants (Kostka, 2000). Soil surfactants are frequently referred to as "wetting agents" by practitioners in the turfgrass industry (Zontek and Kostka, 2012). The proper label of "soil surfactant", however, is a more appropriate term to use from a soil science perspective (Fidanza et al., 2019; Kostka et al., 2008). Surfactants are compounds that lower the surface tension (or interfacial tension) between two liquids, between a gas and a liquid, or between a liquid and a solid. Soil surfactants are employed for many useful purposes and benefits in turfgrass management (Kostka and Fidanza, 2019b). For example, soil surfactants are used by turfgrass managers (i.e., golf course superintendents, greenkeepers, course managers, sports pitch managers) for a variety of purposes, strategies, and benefits, including the improvement with wettability of rootzone soil, alleviation and mitigation of soil water repellency, treatment for localized dry spots or dry patches, for irrigation water use efficiency and optimization, to improve the application, distribution, and efficacy of plant protection products, to improve plant nutrition and fertility programs, to support turf resiliency and recovery during abiotic and biotic stress periods, and as a component of an overall plant and soil health strategy (Moore et al., 2010; Zontek and Kostka, 2012). A survey of golf course superintendents in the USA revealed that soil surfactants are the number one water conservation practice employed on their golf courses (Gelernter et al., 2015). Today, an extensive number of soil surfactant products are available in the marketplace, which has resulted in a great deal of confusion and misinformation for the end-user (Kostka and Fidanza, 2018).

Therefore, the first objective of this review was to determine what research and other supportive literature was published from 2000 to the present on the topic of soil water repellency in turfgrass science. The second objective was to assemble a comprehensive list of soil surfactant products and/or product formulations currently available in the turf industry marketplace in the USA and the UK and Republic of Ireland.

\section{MATERIALS AND METHODS}

Soil water repellency literature in turfgrass science

The Turfgrass Information Center (https://tic.msu.edu) located at Michigan State University (East Lansing, MI, USA), was used to access the on-line database, Turfgrass Information File (TGIF). To date, the TGIF database contains over a quarter million records, with $60 \%$ of those records linked directly to full-text item. TGIF enabled a search for all publications utilizing the keywords search of "soil water repellency" within the discipline of turfgrass science and management. A search parameter timeline was designated as publications from 1 Jan 2000 through 1 Jun 2020, and included three specific categories: (1) refereed journal articles (i.e., peer-reviewed articles published in scientific journals), (2) abstracts, reports, and proceedings, and (3) professional and trade journal articles.

\section{Soil surfactant products in the turf marketplace}

The largest global markets for soil surfactants are the two countries with the largest number of golf courses, the United States and the United Kingdom. To determine the diversity of commercially available products in these markets, we utilized Google and its associated search options (i.e., Google Scholar).
Keywords included: Soil wetting agent, soil surfactant, and manufacturer names and brands. We supplemented online searches with extensive reviews of trade journals and press releases. Other sources included social media, specifically product marketing posts and testimonials via Twitter, as well as tradeshows to obtain further product information and speak directly to company representatives. Formulation compositions were derived from product labels, Safety Data Sheets (SDSs), Chemical Abstracting Service Number databases, and archival online information searches, with all findings further assessed through database analysis of compound synonyms. Separately, searches were conducted via the databases accessible via ESPACE, the USPTO, and Google Patents.

\section{RESULTS AND DISCUSSION}

Soil water repellency literature in turf: Refereed journal articles

From 1 Jan 2000 to 1 Jun 2020, refereed or peer-reviewed articles published in scientific journals ranged from one to eight per year, with three years of no articles, and an overall average of 3.4 articles published per year (Figure 1). The total cumulative number of articles published was 64 , which revealed a linear progression over time (Figure 2), with a slight lag in 2003-2004 and again in 2019, and a noticeable increasing trend during 2010-2018 attributed to more scientists investigating this topic in amenity turf.

\section{Soil water repellency literature in turf: Published abstracts, reports, and proceedings}

From 1 Jan 2000 to 1 Jun 2020, published abstracts, reports, and proceedings ranged from one to fifteen per year, with three years of none produced, with an overall average of 4.6 published works per year (Figure 3 ). The total cumulative number of publications was 87 , which also revealed a linear progression over time (Figure 4). An increasing trend was noticeable at the annual international tri-society meeting of the American Society of Agronomy, Crop Science Society of America, and the Soil Science Society of America, where several abstracts have been presented each year in 2017, 2018, and 2019, on the specific topic of soil surfactant research in turf. Of note, those abstracts

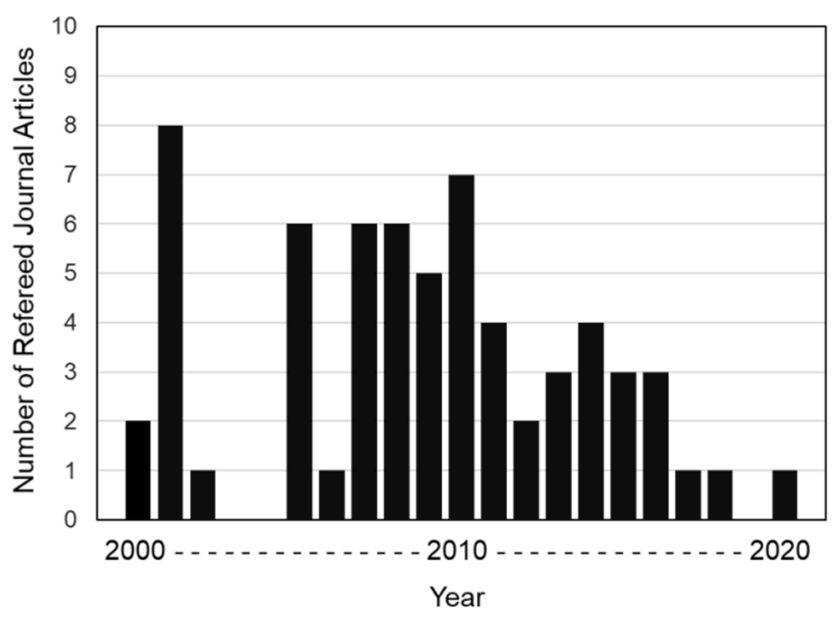

Fig. 1. Number of refereed journal articles (i.e., peer-reviewed articles published in scientific journals) that focuses or includes the topic of soil water repellency in turfgrass science and management, from 1 Jan 2000 to 1 Jun 2020. 


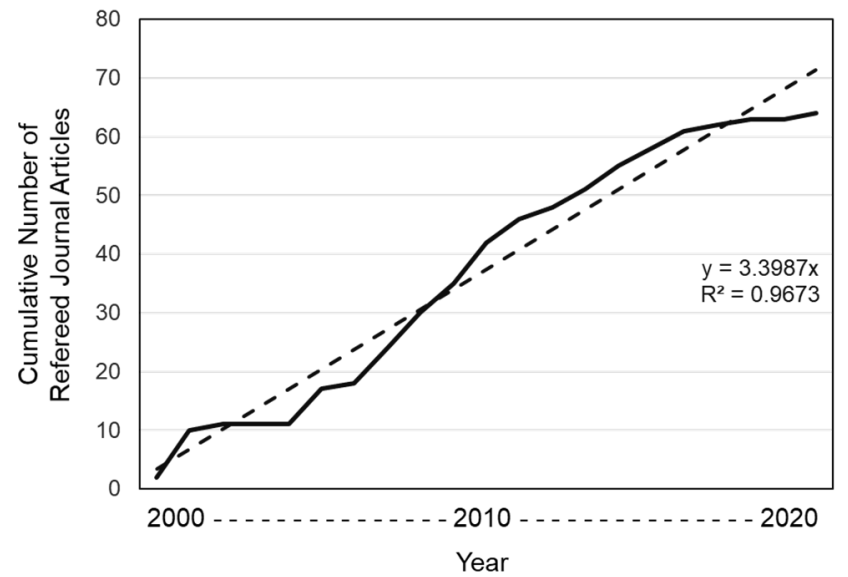

Fig. 2. Cumulative number of refereed journal articles (i.e., peerreviewed articles published in scientific journals) that focuses or includes the topic of soil water repellency in turfgrass science and management, from 1 Jan 2000 to 1 Jun 2020; actual articles ( - ) trendline (- - ).

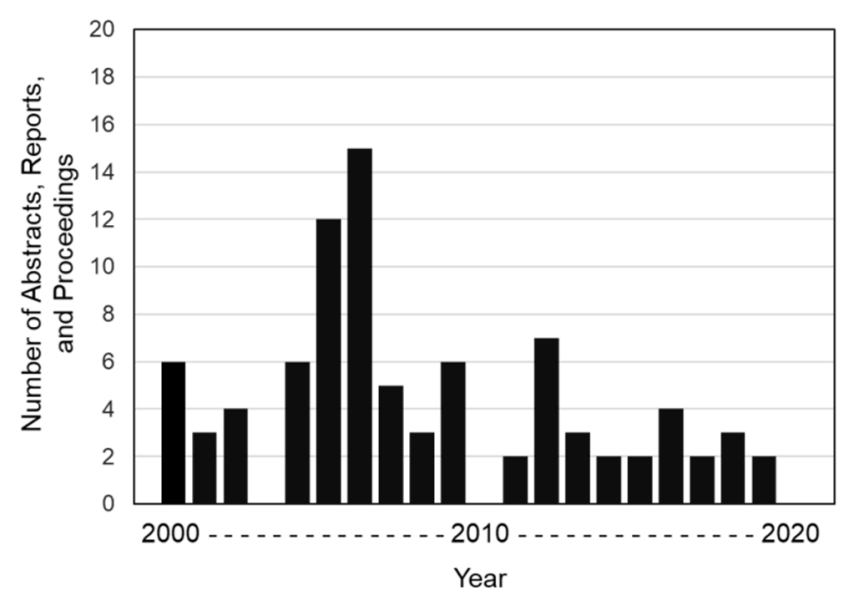

Fig. 3. Number of published abstracts, reports, and proceedings that focuses or includes the topic of soil water repellency in turfgrass science and management, from 1 Jan 2000 to 1 Jun 2020.

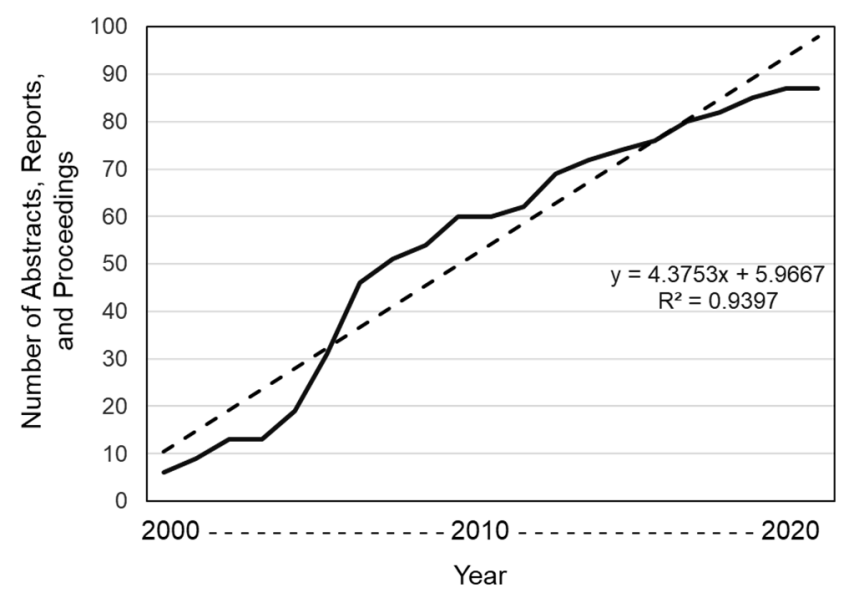

Fig. 4. Cumulative number of published abstracts, reports, and proceedings that focuses or includes the topic of soil water repellency in turfgrass science and management, from 1 Jan 2000 to 1 Jun 2020; actual articles (-) and trendline (---). were not counted in Figures 3 and 4, since the keywords "soil water repellency" were not included in those abstracts. Based on the number of recent research abstracts presented, it is anticipated that more refereed journal articles will be published in the near future on the topic of soil surfactant evaluations and soil water repellency issues in turf.

\section{Soil water repellency literature in turf: Professional and trade journal articles}

From 1 Jan 2000 to 1 Jun 2020, published professional and trade journal articles primarily written for the practitioner audience ranged from one to eighteen per year, with an overall average of 4.5 articles per year (Figure 5). The total cumulative number of publications was 86 , which resembled a linear progression over time (Figure 6). Of note, 18 articles were produced in 2005, which was attributed to research being conducted and presented at international conferences in the early 2000s on those topics of understanding soil water repellency, and the amelioration of soil water repellency using soil surfactants, in turfgrass ecosystems.

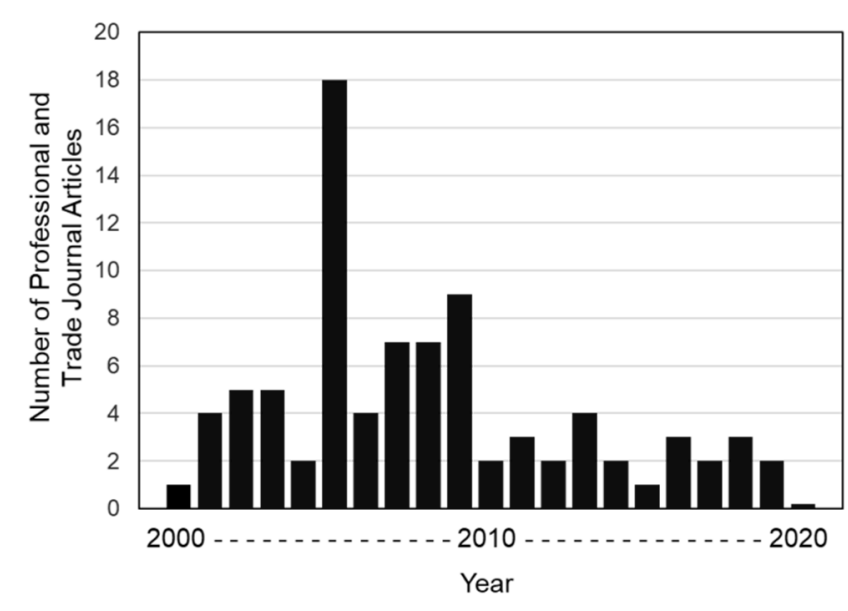

Fig. 5. Number of professional and trade journal articles that focuses or includes the topic of soil water repellency in turfgrass science and management, from 1 Jan 2000 to 1 Jun 2020.

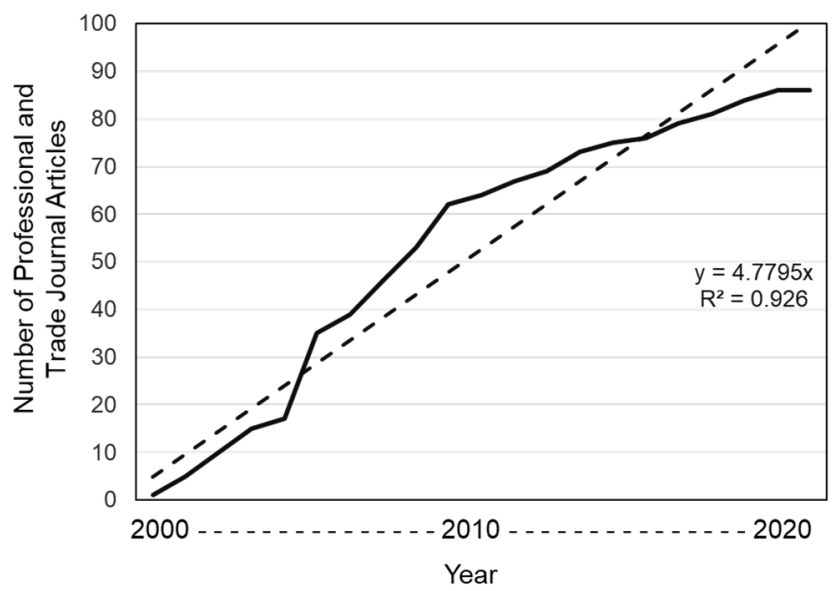

Fig. 6. Cumulative number of professional and trade journal articles that focuses or includes the topic of soil water repellency in turfgrass science and management, from 1 Jan 2000 to 1 Jun 2020; actual articles ( - ) and trendline ( - - ) . 


\section{Soil surfactant products in USA, 2019}

In the early 1990 's, the USA soil surfactant products for turf was composed of a handful of predominately national brands. By 2019, that number swelled to 192 branded soil surfactant formulations being offered by 43 companies in a market with an estimated retail value of \$50-75 million USD (Table 1). The products were classified into chemical class, chemical category, and ultimately into 20 formulation categories based on composition. Evaluating soil surfactant products in the marketplace based on chemical class, most were nonionic surfactants with 142 of 192 (or $74 \%$ ), 18 (or 9\%) were anionic surfactants or blends of anionic and nonionic surfactants, and the remaining
32 (or 17\%) were undisclosed (i.e., no information on composition could be elucidated based on publicly available information). Examining soil surfactants based on formulation category revealed the largest single formulation consisted of the 94 (or 49\%) products composed of block copolymer surfactants. When considering other formulations that also contained block copolymers or structurally modified block copolymers as formulation components, that number reached a total of 112 (or 58\%). The remaining formulation categories within the nonionic chemical class consisted of 30 (or 16\%) surfactants of polyoxyethylene and polyalkylenes blends, alkypolyglucosides, alcohol ethoxylates, a botanical, and an organosilicate.

Table 1. Soil surfactant products for the turf industry in the USA market in 2019.

\begin{tabular}{|c|c|c|c|c|c|}
\hline Chemical Class & $n$ & Chemical Category & $n$ & Formulation Category & $n$ \\
\hline \multirow{17}{*}{ Nonionic } & \multirow{17}{*}{142} & \multirow{8}{*}{ Block Copolymer } & \multirow{8}{*}{112} & Block Copolymer & 94 \\
\hline & & & & Block Copolymer - Alcohol Ethoxylate Blends & 3 \\
\hline & & & & Block Copolymer + Alkylpolyglycoside & 5 \\
\hline & & & & Block Copolymer - Maleic Acid Blends & 3 \\
\hline & & & & Block Copolymer - Solvent Blends & 2 \\
\hline & & & & Modified Methyl Capped Block Copolymer & 1 \\
\hline & & & & Oleic Acid Esters of Block Copolymer & 1 \\
\hline & & & & Other Block Copolymer Blends & 3 \\
\hline & & Alcohol & 2 & Alcohol Ethoxylates & 2 \\
\hline & & Alkylpolyglucoside & 4 & Alkylpolyglucoside & 4 \\
\hline & & Botanical & 1 & Yucca plant extract & 1 \\
\hline & & Organosilicone & 1 & Organosilicone & 1 \\
\hline & & \multirow{2}{*}{ Polyalkylene } & \multirow{2}{*}{5} & Hexahydroxy Polyalkylene Polymers & 1 \\
\hline & & & & Octahydroxy Polyalkylene Polymers & 4 \\
\hline & & \multirow{3}{*}{ Polyoxyethylene } & \multirow{3}{*}{17} & Polyoxyethylene - Alkylpolyglucoside Blends & 2 \\
\hline & & & & Polyoxyethylene - Block Copolymer Blends & 2 \\
\hline & & & & Polysorbate Polyoxyethylene Copolymer & 13 \\
\hline \multirow{2}{*}{ Anioic } & \multirow{2}{*}{18} & \multirow{2}{*}{ Anioic and Blends with Anionics } & \multirow{2}{*}{18} & Anionic Blends & 11 \\
\hline & & & & Blends of Anionic and Nonionic & 7 \\
\hline Unknown & 32 & Not Disclosed & 32 & Not Disclosed & 32 \\
\hline
\end{tabular}

Table 2. Soil surfactant products for the turf industry in the UK and Republic of Ireland markets in 2019.

\begin{tabular}{|c|c|c|c|c|c|}
\hline Chemical Class & $n$ & Chemical Category & $n$ & Formulation Category & $n$ \\
\hline \multirow{19}{*}{ Nonionic } & \multirow{19}{*}{43} & \multirow{11}{*}{ Block Copolymer } & \multirow{11}{*}{32} & Block Copolymer & 19 \\
\hline & & & & Block Copolymer + Alkylpolyglycoside & 3 \\
\hline & & & & Block Copolymer + Fatty Amine + Organosilicone + Acetic Acid & 1 \\
\hline & & & & Block Copolymer + Glycol & 1 \\
\hline & & & & Block Copolymer + Organosilicone & 1 \\
\hline & & & & Block Copolymer + Succinate & 1 \\
\hline & & & & Block Copolymer + Terpene-derived Surfactant & 1 \\
\hline & & & & Block Copolymer + Not disclosed & 2 \\
\hline & & & & Alkyl-terminated Block Copolymer & 1 \\
\hline & & & & Alkyl-terminated Block Copolymer + Block Copolymer & 1 \\
\hline & & & & Oleic Acid Esters of Block Copolymer & 1 \\
\hline & & Alcohol & 1 & Ethoxylated Fatty Alcohols & 1 \\
\hline & & Botanical & 2 & Yucca plant extract & 2 \\
\hline & & Organosilicone & 3 & Organosilicone & 3 \\
\hline & & \multirow[b]{2}{*}{ Other / Not Categorized } & \multirow{2}{*}{2} & Aqueous Hydrophobic Polymer & 1 \\
\hline & & & & Ducosate Sodium Sulfate & 1 \\
\hline & & \multirow{2}{*}{ Polyalkylene } & \multirow{2}{*}{2} & Hexahydroxy Polyalkylene Polymers & 1 \\
\hline & & & & Octahydroxy Polyalkylene Polymers & 1 \\
\hline & & Polyoxyethylene & 1 & Polysorbate Polyoxyethylene Copolymer & 1 \\
\hline \multirow{3}{*}{ Anioic } & \multirow{3}{*}{4} & \multirow{3}{*}{ Anioic and Blends with Anionics } & \multirow{3}{*}{4} & Anionic + Alcohol Ethoxylate & 1 \\
\hline & & & & Anionic + Block Copolymer & 1 \\
\hline & & & & Anioinic - Not disclosed & 2 \\
\hline Unknown & 18 & Not Disclosed & 18 & Not Disclosed & 18 \\
\hline
\end{tabular}




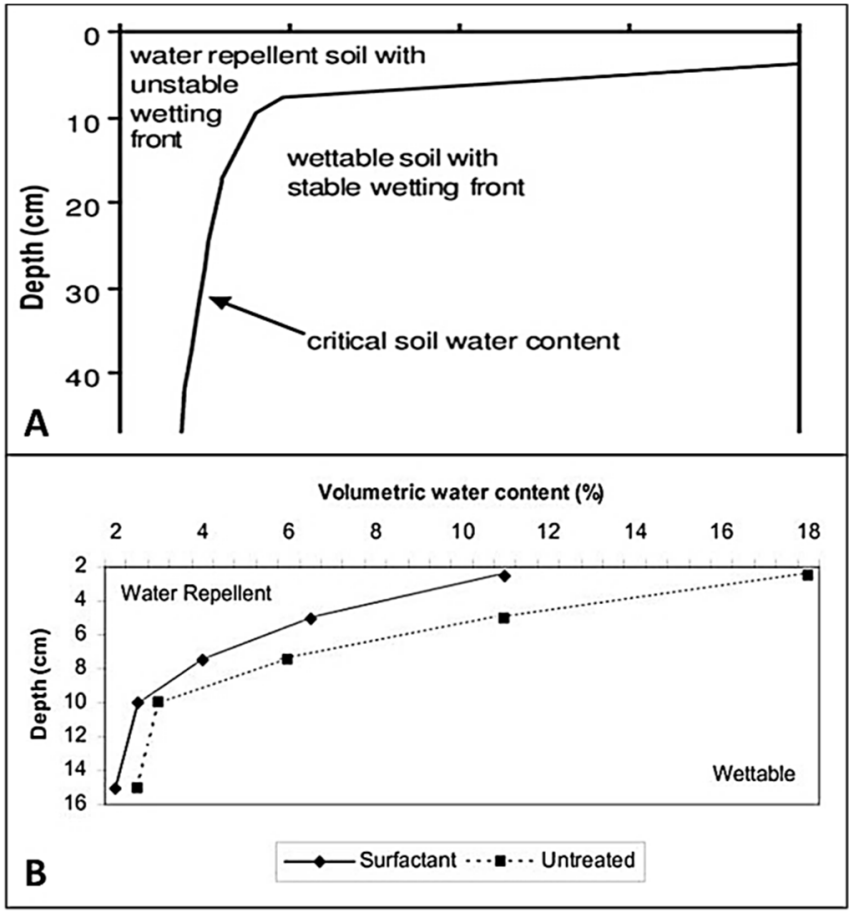

Fig. 7. A: Concept of critical water content derived from investigations on dune sand (from Dekker et al., 2001b), indicating that a rootzone becomes water repellent when the volumetric water content drops below a critical threshold, and this condition can be influenced by rootzone depth. B: Concept of critical water content applied to sand rootzones of a golf course putting green (from Kost$\mathrm{ka}$ et al., 2007b), which was derived from the original concept of Dekker et al. (2001b), indicating that on golf course putting greens with constructed sand rootzones the soil can "flip" or change very quickly from wettable to water repellent, but the use of a soil surfactant can help lower that critical water content threshold. Thus, where soil wettability is less than optimal, soil surfactants in combination with appropriate irrigation and soil cultivation practices can improve soil hydrological behavior resulting in improved irrigation efficiency and water conservation.
Soil surfactant products in United Kingdom and Republic of Ireland, 2019.

While the US is the world's largest golf turf market with over 15,000 golf courses, the United Kingdom and the Republic of Ireland support nearly 3,000 golf courses. In the UK and Ireland, a total of 65 branded soil surfactant formulations are being sold by 18 companies (Table 2), with a retail value not determined. The proportional listing of products based on chemical class is similar to the USA market, with 43 of 65 (or $66 \%$ ) based exclusively on nonionics, 4 of 65 (or $6 \%$ ) as anionics, and 18 of 65 (or 28\%) as unknown. A review of soil surfactants based on formulation category indicated the largest single formulation was the 19 (or 29\%) products composed of block copolymer surfactants. When including other formulations that also contained block copolymers or structurally modified block copolymers as formulation components, that number climbed to a total of 32 (or $49 \%$ ). The remaining formulation categories within the nonionic chemical class consisted of 11 (or 17\%) surfactants of alcohol, botanical, organosilicone, polyalkylene, polyoxyethylene, and two products not categorized to formulation but are listed within the nonionic chemical category.

There are evident parallels between the formulations, with nonionic block copolymer surfactants being well represented in the United States, the United Kingdom, and the Republic of Ireland. A notable difference in the markets is the presence of more organosilicone soil surfactant products in the UK and Ireland, and more alkylpolyglucoside and polyoxyethylene soil surfactant products in the USA. Nonetheless, the dominant presence of nonionic block copolymer surfactants as soil water management products in amenity turf is evident. While chemical analysis of soil surfactants in the non-disclosed formulation category could not be conducted, it is likely that nonionic block copolymer formulations were well represented within that nondisclosed group as well.

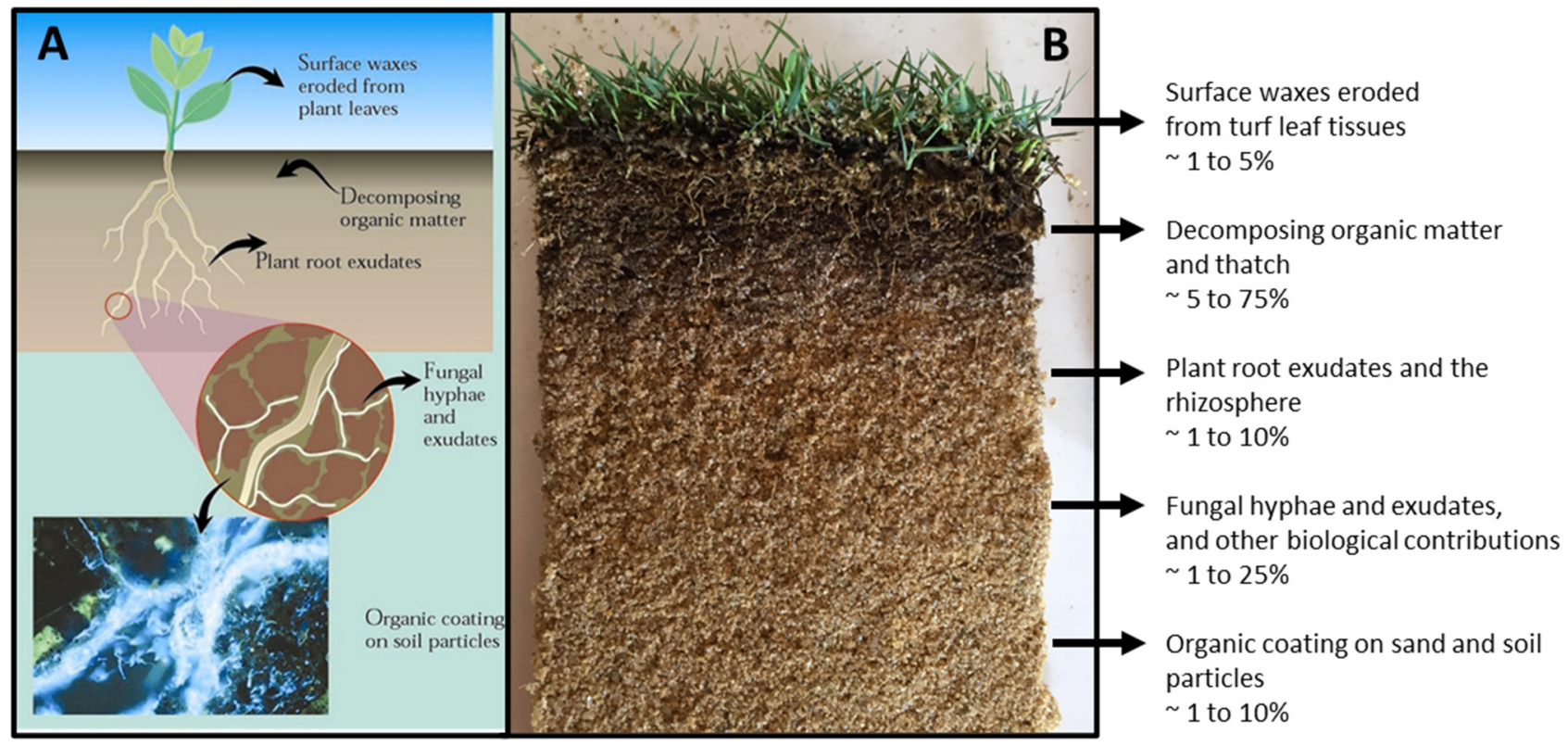

Fig. 8. A: The origin of water repellency from microbiota and decomposing organic matter in the soil, as adapted from Hallett (2007). B: Profile of creeping bentgrass (Agrostis stolonifera) from a golf course fairway, with speculation as to the contribution of various components toward the development of water repellency in the rootzone. 


\section{CONCLUSION}

Dr. Louis Dekker's pioneering research in soil water repellency has enabled turfgrass scientists to understand a diversity of implications with not only water but overall plant and soil health, mobilization of organically bound nitrogen, modification of rootzone and surface moisture heterogeneity, impacts on leaching, and is now leading us to further explore the rhizosphere in turfgrass ecosystems. Of one particular publication in the scientific literature worthy of further insight, the contribution of Dekker et al. (2001b) has led turfgrass scientists as well as practitioners on a journey to a better understanding of not just soil water repellency (Hallett, 2008; Kostka and Fidanza, 2019a), but impacts on flow and rootzone water distribution in the rootzone (Bigelow et al., 2001; Gross, 2016; Kvalbein and Aamlid, 2014). The basic principles Dr. Dekker explored studying those old dunes had direct applicability to issues impacting soils and turf productivity globally (Figure 7), and his research enabled transformative change in how turfgrass scientists investigated soil water repellency in managed amenity turf, and how they looked further into what a soil surfactant could do (Kostka et al., 2007b). To this day, turfgrass scientists are still developing new research-based findings (Figure 8) as guided by Dr. Dekker's early observations (Fidanza, 2007; Fidanza et al., 2007; Hallett et al., 2006; Kostka and Fidanza, 2019a; Kostka et al., 2005, 2008; McMillan et al., 2013; Moore et al., 2010). Moreover, the global turf industry remains the segment where Dr. Dekker's research has had the most influence.

Research on soil surfactant use in the turf industry has expanded dramatically over the past 25-30 years from a single spot treatment to a critical component and commonly accepted practice for water management in amenity turf. What originated as a tool to mitigate dry patch (localized dry spots) has expanded broadly into large scale management of soil water repellency, infiltration and flow phenomena to modify critical rootzone water content as a parameter to be managed for turf health and playability, reducing heterogeneity of rootzone volumetric water content, improving rootzone reservoir recharge and irrigation efficiency, reduced overland flow and leaching, particularly of nutrients and pesticides, improve turf quality, as a component of an overall program to manage abiotic and biotic stresses, and as a component of an overall plant and soil/rhizosphere health program (Kostka and Fidanza, 2019a).

Acknowledgements. Dr. Louis W. Dekker was always welcoming to those of us pursuing research in turfgrass science, and he always insisted that we were included and had the opportunity to participate in the various conferences and symposiums on the topic of soil water repellency. His research in soil physics provided a science-based foundation needed to broaden our understanding of those concepts and critical areas of research for turfgrass science. We are grateful that he shared his enthusiasm and knowledge with us, provided guidance and insights, and more importantly that he was our colleague and friend. Most importantly, he was a mentor.

\section{REFERENCES}

Bigelow, C.A., Bowman, D.C., Cassel, D.K., 2001. Water retention of sand-based putting green mixtures as affected by the presence of gravel sub-layers. International Turfgrass Society Research Journal, 9, 479-486.

Cisar, J.L., Williams. K.E., 1994. Wetting agent effects on turf soil-water repellency. HortScience, 29, 5, 552.

Cisar, J.L., Snyder, R.H., Snyder, G.H., 1997. Alleviating soil- water repellency. International Turfgrass Society Research Journal, 8, 139-145.

Cisar, J.L., Williams, K.E., Vivas, H.E., Haydu. J.J., 2000. The occurrence and alleviation by surfactants of soil-water repellency on sand-based turfgrass systems. Journal of Hydrology, 231-232, 352-358.

DeBano, L.F., 2000. Water repellency in soils: a historical overview. Journal of Hydrology, 231-232, 4-32.

DeBano, L.F., Letey, J. (Eds.), 1969. Proceedings of the Symposium on Water Repellent Soils. University of California, Riverside, 6-10 May 1968, 354 p.

DeBano, L.F., Dekker, L.W., 2000. Water repellency bibliography. Journal of Hydrology, 231-232, 409-432.

Dekker, L.W., Ritsema, C.J., 1994. How water moves in a water repellent sandy soil: 1 . Potential and actual water repellency. Water Resource Research, 30:2507-2517.

Dekker, L.W., Oostindie, K., Ziogas, A.K., Ritsema, C.J., 2001a. The impact of water repellency on soil moisture variability and preferential flow. International Turfgrass Society Research Journal, 9, 498-505.

Dekker, L.W., Doerr, S.H., Oostindie, K., Ziogas, A.K., Ritsema, C.J., 2001b. Water repellency and critical soil water content in a dune sand. Soil Science Society of America Journal, 65, 1667-1674.

Dekker, L.W., Oostindie, K., Kostka, S.J. Ritsema, C.J., 2003. Treating water repellent surface layer with surfactant. In: Ritsema, C.J., Dekker, L.W. (Eds.): Soil Water Repellency: Occurrence, Consequences, and Amelioration, Elsevier, Amsterdam, pp. 313-345.

Dekker, L.W., Oostindie, K., Ritsema, C.J., 2005. Exponential increase of publications related to soil water repellency. Soil Res., 43, 403-441.

Doerr, S.H., Shakesby, R.A., Walsh, R.P.D., 2000. Soil water repellency: Its causes, characteristics and hydrogeomorphological significance. Earth Sci. Rev., 51, 33-65.

Fidanza, M.A., 2007. Characterization of soil properties associated with type-I fairy ring sumptoms in turfgrass. Biologia, 62, 533-536.

Fidanza, M.A., Cisar, J.L., Kostka, S.J., Gregos, J.S., Schlossberg, M.J., Franklin, M., 2007. Preliminary investigation of soil chemical and physical properties associated with type-I fairy ring symptoms in turfgrass. Hydrological Processes, 21, 17, 2285-2290.

Fidanza, M., Kostka, S., Ervin, E., Bigelow, C., 2019. The European Union's view on biostimulants: What may be coming our way. Golf Course Management, 87, 9, 58-62.

Gelernter, W.D., Stowell, L.J., Johnson, M.E., Brown, C.D., Beditz, J.F., 2015. Documenting trends in water use and conservation practices on U.S. golf courses. Crop, Forage and Turfgrass Management, 1, 1, 1-10.

Gross, P., 2016. Five things to know about water management during summer. USGA Green Section. Source: https://www.usga.org/course-care/regional-updates/westregion/five-things-to-know-about-water-management-ongreens-during-summ.html.

Hallett, P.D., 2007. An introduction to soil water repellency. In: Proceedings of the $8^{\text {th }}$ International Symposium on Adjuvants for Agrochemicals (ISAA 2007), 13 p.

Hallett, P.D., 2008. A brief overview of the causes, impacts and amelioration of soil water repellency - a review. Soil and Water Research, 3, S21-S29.

Hallett, P.D., White, N.A., Ritz, K., 2006. Impact of basidiomycete fungi on the wettability of soil contaminated with a hydrophobic polycyclic aromatic hydrocarbon. Biologia, 61, Suppl. 19, S334-S338. 
Kostka, S.J., 2000. Amelioration of water repellency in highly managed soils and the enhancement of turfgrass performance through the systematic application of surfactants. Journal of Hydrology, 231-232, 359-368.

Kostka, S.J., Fidanza, M., 2018. The quagmire that is soil surfactants in golf and sports turf management. ASA, CSSA and SSSA International Annual Meetings. Agronomy Abstracts, p. 113267.

Kostka, S.J., Fidanza, M., 2019a. Revisiting concepts on the development of soil water repellency. ASA, CSSA and SSSA International Annual Meetings. Agronomy Abstracts, p. 122260.

Kostka, S., Fidanza, M., 2019b. Soil surfactant usage based on solid science. Golf Course Industry, online. https://www.golfcourseindustry.com/article/soil-surfactantresearch-guidance/

Kostka, S.J., Cisar, J.L., Short, J.R., Mane, S., 1997. Evaluation of soil surfactants for the management of soil water repellency in turfgrass. International Turfgrass Society Research Journal, 8, 485-494.

Kostka, S.J., Dekker, L.W., Oostindie, K., Ritsema, C.J., Miller, C.M., Karcher, D.E., 2002. Advances in understanding and managing water repellent soils. In: Irrigation Show 2002: Technical Session Proceedings. Irrigation Association, Falls Church, VA, pp. 1-8.

Kostka, S.J., Cisar, J.L., Ritsema, C.J., Dekker, L.W., Franklin, M.A., Mitra, S., McCann, S.E., 2005. Surfactants and soil water repellency in golf course soils - water use and environmental implications. In: Proceedings of the 25th Irrigation Association Conference, pp. 235-246.

Kostka, S.J., Cisar, J.L., Mitra, S., Park, D.M., Ritsema, C.J., Dekker, L.W., Franklin, M.A, 2007a. Irrigation efficiency Surfactants can save water and help maintain turfgrass quality. Golf Course Industry, 19, 4, 91-95.

Kostka, S.J., Dekker, L., Ritsema, C., Cisar, J.L., Franklin, M.K., 2007b. Surfactants as management tools for ameliorating soil water repellency in turfgrass systems. In: Proceedings of the $8^{\text {th }}$ International Symposium on Adjuvants for Agrochemicals (ISAA 2007), 7 .

Kostka, S.J., Dekker, L.W., Oostindie, K., Mauser, K., Franklin, M.A., 2008. May surfactants affect more than wetting in water repellent soils? 1st European Turfgrass Society Conference Proceedings. Pisa, Italy, 1 May 2008, pp. 109-110.

Kvalbein, A., Aamlid, T.S., 2014. Irrigation of turf on golf courses - a greenkeeper guide to understanding the theory and practice. Publication of the Scandinavian Turfgrass and Environment Research Foundation; Stockholm, Sweden.

Letey, J., Osborn, J.F., Valoris, N., 1969. Wetting agents and water repellent soils. Southern Regional Turf Research Committee Report, 1968-69. 8 p.

Letey, J., Welch, N., Pelishek, R.E., Osborn, J., 1963. Effect of wetting agents on irrigation of water repellent soils. California Turfgrass Culture, 13, 1, 1-2.

McMillan, M.F. Kostka, S., Boerth, T., Fidanza, M., Bigelow, C., Cisar, J., Soldat, D., Karas, I., Williams, K., 2013. Moni- toring seasonal soil water repellency in USA golf course putting greens. International Turfgrass Society Research Journal, 12, 815-818.

Miller, R.H., Wilkinson, J.F., 1977. Nature of the organic coating on sand grains of non-wettable golf greens. Soil Sci. Soc. Am. J., 41, 1203-1204.

Moody, D.R., Schlossberg, M.J., Archibald, D.D., McNitt, A.S., Fidanza, M.A., 2009. Soil water repellency development in amended sand rootzones. Crop Science, 49, 5, 1885-1892.

Moore, D., Kostka, S.J., Boerth, T.J., Franklin, M., Ritsema, C.J., Dekker, L.W., Oostindie, K., Stoof, C., Wesseling, J., 2010. The effect of soil surfactants on soil hydrological behavior, the plant growth environment, irrigation efficiency and water conservation. J. Hydrol. Hydromech., 58, 3, 142148.

Müller, K., Deurer, M., 2011. Review of the remediation strategies for soil water repellency. Agr. Ecosyst. Environ., 144, 208-221.

Park, D.M., Cisar, J.L., Williams, K.E., Snyder, G.H., 2004. Alleviation of soil water repellency in sand based bermudagrass in South Florida. Acta Horticulturae, 661, 111-115.

Ritsema, C.J., Dekker, L.W. (Eds.), 2003. Soil Water Repellency. Elsevier Science, Amsterdam.

Schlossberg, M.J., McNitt, A.S., Fidanza, M.A., 2005. Development of water repellency in sand-based root zones. International Turfgrass Society Research Journals, 10, 11231130.

Snyder, G.H., 1969. Soil water repellency. In: Proceedings of the Florida Turf-Grass Management Conference. 23-25 September 1969. Florida Turfgrass Association, Orlando, FL, pp. 105-106.

Tucker, K.A., Karnok, K.J., Radcliffe, D.E., Landry, Jr., G., Roncadori, R.W., Tan, K.H., 1990. Localized dry spots as caused by hydrophobic sands on bentgrass greens. Agronomy Journal, 82, 549-555.

Wallis, M.G., Horne, D.J., 1992. Soil water repellency. Advances in Soil Science, 20, 91-146.

Wallis, M.G., Horne, D.J., McAuliffe, K.W., 1990. A study of water repellency and its amelioration in a yellow-brown sand: 1. Severity of water repellency and the effects of wetting and abrasion. New Zealand Journal of Agricultural Research, 33, 1, 139-144.

Wilkinson, J.F., Miller, R.H., 1978. Investigation and treatment of localized dry spots on sand golf greens. Agronomy Journal, 70, 299-304.

York, C.A., Canaway, P.M., 2000. Water repellent soils as they occur on UK golf greens. Journal of Hydrology, 231-232, 126-133.

Zontek, S.J., Kostka, S.J., 2012. Understanding the different wetting agent chemistries: A surfactant is a wetting agent but a wetting agent may not be a surfactant. Surprised? USGA Green Section Record, 50, 15, 1-6.

Received 23 June 2020 Accepted 17 July 2020 